\title{
POTENSI PEMBERIAN EKSTRAK BUAH DELIMA (Punica granatum L) TERHADAP KUALITAS SPERMATOZOA TIKUS PUTIH (Rattus norvegicus) YANG TERPAPAR PANAS
}

\section{THE POTENTIAL OF POMEGRANATE (Punica granatul $l$ ) FRUIT EXTRACT FOR THE QUALITY WHITE RAT (Rattus norvegicus) SPERMATOZOA EXPOSED TO HEAT}

\author{
Nucifera Fadhillah Santoso ${ }^{1)}$, *Budi Utomo ${ }^{2)}$, Mirni Lamid ${ }^{3)}$ \\ ${ }^{1)}$ Student, ${ }^{2)}$ Department of Veterinary ReproductionFaculty of Veterinary Medicine, ${ }^{3)}$ Animal \\ Husbandry Departemen, Faculty of Veterinary Medicine, Universitas Airlangga \\ *Corresponding author: email: budi_reprovet@yahoo.com
}

\begin{abstract}
The purpose of this research was to determine the effect of pomegranate (Punica granatul $l$ ) fruit extract for spermatozoa quality including the motility, viability and membrane integrity of spermatozoa. The researchused 20 male white rats (Rattus norvegicus) with 200-300 gram average body weight. P0 as control was given with CMC Na $0.5 \%$. P1 used $75 \mathrm{mg} / \mathrm{kg}$ BW dose of extract, P2used $150 \mathrm{mg} / \mathrm{kg} \mathrm{BW}$ dose of extract, P3 used $300 \mathrm{mg} / \mathrm{kg} \mathrm{BW}$ dose of extract. The treatment was given perorally for 14 days. The experiment was used completely random design (CRD). The result of this study was analyzed with ANOVA followed by Tukey Test $(\mathrm{p}<0.05)$. The result showed that there was significant effect from therapy on the quality of rats spermatozoa. The difference of spermatozoa's concentration between first treatment group P1 and control treatment group is not significant, while the treatment other result showed between the second treatment group and the control group P0. A significant difference occurs in the percentage of motility, viability and membrane integrity. The treatment from P2 group showed the best result in maintaining the quality of rats spermatozoa.
\end{abstract}

Key words: Spermatozoa, pomegranate fruit extract, motility, viability, and membrane integrity

\section{Pendahuluan}

Usaha peternakan sebagai penghasil sumber protein hewani diharapkan dapat memenuhi kebutuhan konsumsi protein hewani masyarakat Indonesia. Akan tetapi usaha peternakan di Indonesia menghadapi banyak kendala sampai saat ini yang berakibat terhadap rendahnya produktivitas dan populasi ternak.Bidang reproduksi adalah salah satu kendala yang dihadapi para peternak seperti halnya rendahnya libido yang mempengaruhi kualitas spermatozoa. Salah satu alternatif menentukan tingkat kesuburan hewan jantan adalah dengan pemeriksaan kualitas spermatozoa (Utoyo,2008). Kualitas spermatozoa merupakan salah satu tolak ukur untuk mengukur kualitas fertiletas dari suatu individu sel-sel spermatogenik seperti spermatogonia, spermatosit dan spermatid merupakan indikator terbentuknya spermatozoa, sehingga keberadaan selsel spermatogenik di tubulus seminiferus testis merupakan titik tolak untuk menilai kualitas fertilitas spermatozoa testis (Zheng dan Qin,2007).

Buah delima (Punica granatum L) merupakan salah satu sumber antioksidan dari tumbuh-tumbuhan dengan kandungan polyphenol yang cukup tinggi (Aviram et al., 2014). Salah satu sepat tersebut merupakan tanda didalamnya mengandung senyawa polyphenol sebagai antioksidan mencapai $26 \%$ dari seluruh kandungan yang ada didalamnya. Buah delima juga kaya akan fitosterol.Fitosterol juga tahan terhadap oksidasi, sehingga dapat digolongkan antioksidan pangan. Buah delima yang mengandung antioksidan berperan dalam menangkap radikal bebas (Astawan,2008).

Jenis antioksidan yang ada di buah delima salah satunya adalah polyphenol yang tediri dari flavonoid, tannin, dan vitamin C. Tanin dan Flavonoid termasuk salah satu antioksidan kuat sebagai pengawet alami. Komposisi dalam Tanin merupakan polyphenol yang banyak di buah delima. Salah 
satu jenis tannin yang terkandung dalam buah delima adalah ellagitanin.

Berdasarkan latar belakang tersebut, maka penelitian ini untuk mengetahui pengaruh flavonoid didalam buah delima $(P u$ nica granatum $L$ )terhadap kualitas spermatozoa pada tikus putih (Rattus norvegicus)

\section{Rumusan Masalah}

1.Apakah ekstrak buah delima (Punica granatum $L$ ) berpotensi dalam mempertahankan motilitas spermatozoa tikus putih (Rattus norvegicus) yang terpapar panas?

2. Apakah ekstrak buah delima (Punica granatum $L$ ) berpotensi dalam mempertahankan viabilitas spermatozoa tikus putih (Rattus norvegicus) yang terpapar panas ?

3. Apakah ekstrak buah delima (Punica granatum $L$ ) berpotensi dalam mempertahankan integritas membran spermatozoa tikus putih (Rattus norvegicus) yang terpapar panas?

\section{Tujuan Penelitian}

1.Mengetahui potensi ekstrak buah delima (Punica granatum) terhadap motilitas spermatozoa tikus putih (Rattus norvegicus) yang terpapar panas

2. Mengetahui potensi ekstrak buah delima (Punica granatum L) viabilitas spermatozoa tikus putih (Rattus norvegicus) yang terpapar panas

3. Mengetahui potensi ekstrak buah delilma (Punica granatum L) terhadap motilitas spermatozoa tikus putih (Rattus norvegicus) yang terpapar panas

\section{Manfaat Hasil Penelitian}

1.Memberikan informasi untuk mengetahui potensi dari buah delima (Punica granatum ) menjadi salah satu pilihan antioksidan yang dapat mempertahankan kualitas motilitas spermatozoa tikus putih ( $R a$ ttus norvegicus) yang terpapar panas sehingga bisa dijadikan acuan untuk mempertahankan potensi spermatozoa.

2. Memberikan informasi untuk mengetahui potensi dari buah delima (Punica granatum ) menjadi salah satu pilihan antioksidan yang dapat mempertahankan kualitas viabilitas spermatozoa tikus putih ( $R a-$ ttus norvegicus) yang terpapar panas sehingga bisa dijadikan acuan untuk mempertahankan potensi spermatozoa.
3.Memberikan informasi untuk mengetahui potensi dari buah delima (Punica granatum ) menjadi salah satu pilihan antioksidan yang dapat mempertahankan kualitas integritas membran spermatozoa tikus putih (Rattus norvegicus) yang terpapar panas sehingga bisa dijadikan acuan untuk mempertahankan potensi spermatozoa.

\section{Metode Penelitian}

Tikus dikelompokan secara random dan dibagi 4 kelompok, sebelum dilakukannya pemberian dosis terlebih dahulu tikus dijemur dibawah sinar matahari selama 15 selama 14 hari secara berturut untuk mendapatkan radikal bebas secara langsung. Kelompok kontrol: lima ekor tikus jantandiberi pelarut CMC Na 0,5\%, kelompok secara peroral, P1: lima ekor tikus diberi ekstrak buah delima dengan dosis $75 \mathrm{mg} / \mathrm{kgBB}$ secara peroral, P2: lima ekor tikus diberi ekstrak buah delima $150 \mathrm{mg} / \mathrm{kgBB}$ secara peroral, P3:lima ekor tikus diberi ekstrak buah delima dengan dosis $300 \mathrm{mg} / \mathrm{kgBB}$ secara peroral. Perlakuan dilakukan selama 14 hari berturutturut di hari ke-15 di euthanasia dengan ether dengan pembedahan abdomen untuk mengambil organ testis kserta saluran epididimis, pengambilan spermatozoa dari saluran cauda epididimis dan dilakukan pemeriksaan motilitas, viabilitas dan integritas membran spermatozoa pada tikus putih.

Hasil penelitian dihitung dengan uji ANOVA dilanjutkan dengan uji tukey HSD (Honestly significant difference) (Kusriningrum,2008).

\section{Hasil dan Pembahasan}

Berdasarkan hasil pemeriksaan presentase motilitas spermatozoa tikus putih pada perlakuan kontrol (PO) menunjukkan hasil presentase motilitas sebesar 55\%. Pada kelompok P1 menunjukkan hasil presentase motilitas sebesar 58\% sementara pada kelompok P2 menunjukkan presentase $68 \%$ yang merupakan motilitas tertinggi dalam penelitian dapat terlihat bahwa pemberian dosis optimallebih dapat mempertahankan pergerakan motilitas spermatozoa untuk mencapai sel telur, sebab kemampuan spermatozoa dalam membuahi sel telur sangat bergantung terhadap daya motilitas dan integritas membran spermatozoa 
(Srivastava et al.,2006). Sedangkan pada kelompok P3 menunjukkan presentase motilitas sebesar $65 \%$ mengalami penurunan diduga dikarenakan oleh kandungan dalam flavonoid yaitu tannin pada buah delima yang diberikan sudah melewati batas optimal dalam pemberian dosis (Winarno, 1997). Hasil presentase selengkapnya dapat dilihat pada tabel 1 .

Hasil presentase viabillitas pada penelitian ini menunjukan bahwa 80,20 $\pm 11,03$ dengan perlakuan pemberian dosis 150 $\mathrm{mg} / \mathrm{kgBB}$. Hasil ini menunjukan rataan tertinggi dari hasil viabilitas dengan dosis yang berbeda. Pada pemberian dosis yang berbeda yaitu $75 \mathrm{mg} / \mathrm{kgBB}$ dan perlakuan kontrol tidak diberikan ekstrak buah delima menunjukkan hasil yang tidak berbeda nyata Hal ini berarti flavonoid yang terkandung dalam buah delima berpengaruh dalam mempertahankan keutuhan membran spermatozoa yang dipercaya dapat melindungi spermatozoa dari paparan radikal bebas.

Pada perlakuan pemberian dosis 300 $\mathrm{mg} / \mathrm{kgBB}$ menunjukan hasil terendah dan menyebabkan penurunan keutuhan spermatozoa pada tikus putih. Penurunan tersebut bisa dikarenakan kepala spermatozoa tidak dapat terlindungi oleh membran sitoplasma yang telah rusak akibat ketidakseimbangan dosis dan radikal bebas sehingga akan mudah menghisap warna hingga dikatakan presentase sperma yang termasuk mati (Nugraheni, 2003). Nilai presentase viabilitas dapat dilihat di tabel 2.
Hasil rataan presentase integritas membran pada penelitian ini menunjukkan bahwa pemberian dosis $150 \mathrm{mg} / \mathrm{kgBB}$ hasil $38,80 \pm 4,14$. Hasil ini menunjukan rataan tertinggi dari hasil integritas dalam penelitian ini. Pada kadar dosis buah delima tertinggi setelah itu adalah pemberian dosis $300 \mathrm{mg} / \mathrm{kgBB}$ yaitu $30,60 \pm 4,27$. Pada perlakuan pemberian dosis $75 \mathrm{mg} / \mathrm{kgBB}$ menunjukan hasil $24,80 \pm 6,05$. Sementara itu perlakuan kontrol tanpa pemberian ekstrak buah delima menunjukan hasil 27,20 \pm 5,63 . Dari data diatas bahwa flavonoid yang terkandung dalam antioksidan buah delima berpengaruh yang dapat meredam radikal hidroksil $(\mathrm{OH})$ sebagai insiator terjadinya reaksi berantai peroksida lipid membrane sel yang dipicu oleh radikal hidroksil (Middleton et al.,2008).Sementara itu pada pemberian dosis $300 \mathrm{mg} / \mathrm{kgBB}$ hasil tersebut hanya 30,60 \pm 4,27 lebih kecil dengan pemberian dosis yang lebih rendah yaitu $150 \mathrm{mg} / \mathrm{kgB}$, Hal ini dikarenakan membran spermatozoa berada dibawah ancaman kerusakan oksidatif karena mengandung poli asam lemak tak jenuh dalam jumlah besar dan relatif kurangnya enzim antioksidan dalam sitoplasma. Kerusakan oksidatif lipid membran sel akan mengubah komposisi asam lemak membran spermatozoa sehingga menghasilkan integritas membran spermatozoa yang rendah (Sharma and garu,2011). Nilai presentase viabilitas dapat dilihat di tabel 2.

Tabel 1.Hasil pemeriksaan rataan motilitas spermatozoa tikus putih

\begin{tabular}{cc}
\hline Perlakuan & Motilitas $(\overline{\mathbf{X}} \pm$ SD\% $)$ \\
\hline P0 & $55 \pm 5,2$ \\
P1 & $58 \pm 4,1$ \\
P2 & $68 \pm 1,5$ \\
P3 & $65 \pm 0$ \\
\hline
\end{tabular}

Tabel 2 Rataan presentase rataan viabilitas spermatozoa tikus putih (Rattus norvegicus)

\begin{tabular}{cc}
\hline Perlakuan & Viabilitas Spermatozoa \\
& $(\overline{\mathbf{X}} \pm$ SD, \%) \\
\hline (P0) & $61,00^{\mathrm{a}} \pm 8,33$ \\
$(\mathbf{P 1})$ & $60,20^{\mathrm{a}} \pm 5,80$ \\
$(\mathbf{P 2})$ & $80,20^{\mathrm{b}} \pm 11,03$ \\
$\mathbf{( P 3 )}$ & $69,20^{\mathrm{ab}} \pm 2,38$ \\
\hline
\end{tabular}

Superskrip yang berbeda dalam satu kolom yang sama menunjukan perbedaan yang nyata $(\mathrm{p}<0,05)$. 
Tabel 3 Hasil pemeriksaan rataan integritas membran spermatozoa tikus putih (Rattus norvegicus)

\begin{tabular}{cc}
\hline Perlakuan & $\begin{array}{c}\text { Integritas Membran Spermatozoa } \\
(\overline{\mathbf{X}} \pm \mathbf{S D}, \boldsymbol{\%})\end{array}$ \\
\hline $\mathbf{( P 0 )}$ & $27,20^{\mathrm{a}} \pm 5,63$ \\
$(\mathbf{P 1})$ & $24,80^{\mathrm{a}} \pm 6,05$ \\
$(\mathbf{P})$ & $38,80^{\mathrm{b}} \pm 4,14$ \\
$(\mathbf{P 3})$ & $30,60^{\mathrm{ab}} \pm 4,27$ \\
\hline
\end{tabular}

Superskrip yang berbeda dalam satu kolom yang sama menunjukan perbedaan yang nyata $(\mathrm{p}<0,05)$

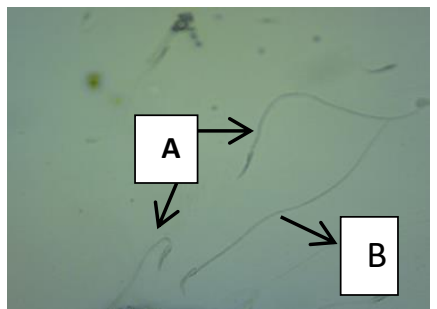

Gambar 1. Integritas membran spermarozoa tikus putih yang telah di uji dngan HOST test (A: integritas membran spermatozoa utuh ; B : Integritas membran spermatozoa yang tidak utuh )

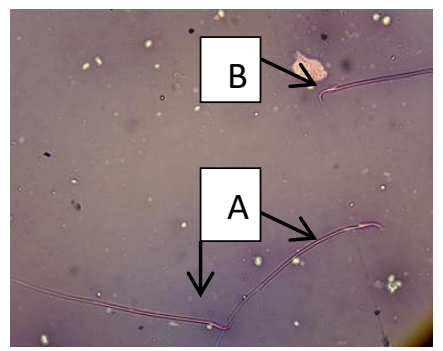

Gambar 2. Viabilitas spermatozoa tikus putih dengan pewarnaan eosin 2\% ( A: Viabilitas spermatozoa hidup, B:Viabilitas spermatozoa mati)

\section{Kesimpulan}

1.Pemberian ekstrak buah delimayang diberikan secara peroral dengan pemberian dosis optimal dapat berpotensi dalam mempertahankan motilitasspermatozoa tikus putih (Rattus norvegicus) yang terpapar panas.

2.Pemberian ekstrak buah delimayang diberikan secara peroral dengan pemberian dosis optimal dapat berpotensi dalam mempertahankan viabilitasspermatozoa tikus putih (Rattus norvegicus) yang terpapar panas.

Pemberian ekstrak buah delimayang diberikan secara peroral dengan pemberian dosis optimal dapat berpotensi dalam mempertahankan integritas membran spermatozoa tikus putih (Rattus norvegicus) yang terpapar panas.

\section{Daftar Pustaka}

Astawan. M, 2008. Sehat Dengan Buah. Dian Rakyat. Jakarta. 103-104

Aviram M. 2014.Methods Of Using Pomegranate Extracts for Treating Diabetes Related Atherosclerotic Complications in Humans. Google Patents.

Nugraheni T., O.A. Parama, dan T. Widiyani. 2003. Pengaruh Vitamin C Terhadap Perbaikan Spermatogenesis dan Kualitas Spermatozoa Mencit (Mus musculus L.) Setelah pemberian ekstrak tembakau (Nikotiana tabacum L.). Biofarmasi. 1(1): 13-7

Sharma T.R. and S. Agarwal. 2011. Multiple Biological Activities of aloe Barbadenis (Aloe Vera): An Overview. Asian Journal of Pharmacy $\&$ Life Science.1(2).

Utoyo, S. 2008. Geografi : Membuka Cakrawala Dunia. PT. Grafindo Media Pratama. Jakarta. 
Winarno, F.G. 1997. Kimia Pangan dan Gizi. PT Gramedia Pustaka Utama. Jakarta.
Zheng, C., and L. Qin. 2007. Chemical components of Centella asiatica and their bioactivities. J Chinese Integ Med. 5: 348-351. 